IVYSPRING INTERNATIONAL PUBLISHER

\section{International Joumal of Biological Sciences}

2012; 8(2):187-194

Short Research Communication

\title{
The Adhesion Modulating Properties of Tenascin-W
}

\section{Florence Brellier ${ }^{1 *}$, Enrico Martina ${ }^{1,2^{*}}$, Matthias Chiquet ${ }^{3}$, Jacqueline Ferralli1, Michael van der Heyden ${ }^{4}$, Gertraud Orend ${ }^{4}$, Johannes C. Schittny ${ }^{5}$, Ruth Chiquet-Ehrismann ${ }^{1,2}$ and Richard P. Tucker6, ${ }^{\square}$}

1. Friedrich Miescher Institute for Biomedical Research, Novartis Research Foundation, CH-4058 Basel, Switzerland.

2. University of Basel, Faculty of Science, $\mathrm{CH}-4056$ Basel, Switzerland.

3. Department of Orthodontics and Dentofacial Orthopedics, University of Bern, CH-3010 Bern, Switzerland.

4. Inserm, U682, Strasbourg, F-67200 France, University Strasbourg, UMR-S682, Strasbourg F-67081, France.

5. Institute of Anatomy, University of Bern, CH-3000 Bern, Switzerland.

6. Department of Cell Biology and Human Anatomy, University of California at Davis, Davis, California 95616 USA.

* These authors contributed equally to this work.

Corresponding author: Department of Cell Biology and Human Anatomy, University of California at Davis, Davis, California 95616 USA. Tel: 001530752 0238; fax: 001530752 8520; E-mail: rptucker@ucdavis.edu.

(C) Ivyspring International Publisher. This is an open-access article distributed under the terms of the Creative Commons License (http://creativecommons.org/ licenses/by-nc-nd/3.0/). Reproduction is permitted for personal, noncommercial use, provided that the article is in whole, unmodified, and properly cited.

Received: 2011.07.20; Accepted: 2011.12.13; Published: 2011.12.20

\begin{abstract}
Tenascins are extracellular matrix glycoproteins associated with cell motility, proliferation and differentiation. Tenascin- $C$ inhibits cell spreading by binding to fibronectin; tenascin- $R$ and tenascin-X also have anti-adhesive properties in vitro. Here we have studied the adhesion modulating properties of the most recently characterized tenascin, tenascin-W. $\mathrm{C} 2 \mathrm{Cl} 2$ cells, a murine myoblast cell line, will form broad lamellipodia with stress fibers and focal adhesion complexes after culture on fibronectin. In contrast, $\mathrm{C} 2 \mathrm{Cl} 2$ cells cultured on tenascin-W fail to spread and form stress fibers or focal adhesion complexes, and instead acquire a multipolar shape with short, actin-tipped pseudopodia. The same stellate morphology is observed when $\mathrm{C} 2 \mathrm{Cl} 2$ cells are cultured on a mixture of fibronectin and tenascin-W, or on fibronectin in the presence of soluble tenascin-W. Tenascin-W combined with fibronectin also inhibits the spreading of mouse embryo fibroblasts when compared with cells cultured on fibronectin alone. The similarity between the adhesion modulating effects of tenascin- $W$ and tenascin- $C$ in vitro led us to study the possibility of tenascin-W compensating for tenascin- $C$ in tenascin-C knockout mice, especially during epidermal wound healing. Dermal fibroblasts harvested from a tenascin-C knockout mouse express tenascin-W, but dermal fibroblasts taken from a wild type mouse do not. However, there is no upregulation of tenascin- $W$ in the dermis of tenascin-C knockout mice, or in the granulation tissue of skin wounds in tenascin-C knockout animals. Similarly, tenascin- $X$ is not upregulated in early wound granulation tissue in the tenascin- $C$ knockout mice. Thus, tenascin- $W$ is able to inhibit cell spreading in vitro and it is upregulated in dermal fibroblasts taken from the tenascin- $C$ knockout mouse, but neither it nor tenascin-X are likely to compensate for missing tenascin- $\mathrm{C}$ during wound healing.
\end{abstract}

Key words: tenascin, extracellular matrix, fibronectin, wound healing, C2C12.

\section{Introduction}

Tenascins are a family of extracellular matrix glycoproteins capable of influencing cell proliferation, fate and behavior by modifying cell adhesion either directly via their cell surface receptors or indirectly through interactions with other matrix molecules (1). The first member of the family to be characterized as 
'anti-adhesive' was tenascin-C. Cells cultured on substrata coated with tenascin- $C$ fail to spread, and cells also fail to spread on substrata formed from mixtures of tenascin- $C$ and fibronectin, or on fibronectin-coated substrata in the presence of soluble tenascin- $C$ (2-7). The adhesion modulating properties of tenascin-R $(8,9)$ and tenascin-X (10-12) are also well known.

Tenascin- $W$ is the most recently discovered member of the tenascin gene family. Its expression during development is largely limited to smooth muscle, bone and the stroma of certain tumors (13-16). The addition of tenascin- $W$ to the medium over osteoblasts cultured on fibronectin prevents them from spreading, and when these cells are cultured on tenascin-W they remain rounded (15). Moreover, in transwell assays soluble tenascin-W promotes the migration of tumor-derived cell lines (16) and osteoblasts (17) across a fibronectin-coated filter. These results suggest that tenascin- $W$ may share some of the anti-adhesive properties of other tenascins.

The tenascin-C knockout mouse was first reported to develop normally (18), but closer examination led to the identification of a number of developmental abnormalities and well as abnormal responses to trauma (1). Tenascin-C is upregulated in the granulation tissue at the borders of skin wounds (19) where it is associated with the migration and proliferation of myofibroblasts and epidermis. However, skin wounds have been reported to heal normally in the tenascin-C knockout mouse (20). We therefore speculated that in these mice tenascin- $W$, if it has anti-adhesive properties, might compensate for tenascin- $C$ in healing wounds.

Here we have cultured $\mathrm{C} 2 \mathrm{C} 12$ cells on tenascin-W-coated substrata either alone or in combination with fibronectin and show that tenascin-W shares adhesion modulating properties with tenascin-C. We then show that tenascin- $W$ is expressed by fibroblasts from the dermis of the tenascin-C knockout mouse, but not by fibroblasts derived from a wild type mouse. Finally, we examined the granulation tissue of healing skin wounds in the tenascin-C knockout mouse for upregulation of tenascin-W.

\section{Materials and methods}

Proteins and antibodies. Fibronectin was isolated from medium conditioned by primary mouse embryonic skin fibroblasts. Medium (approximately $700 \mathrm{ml}$ ) from confluent 4th passage cultures was collected and concentrated 30 fold by precipitation with ammonium sulfate. The concentrated conditioned medium was dialyzed against $\mathrm{Ca}^{++} / \mathrm{Mg}^{++}$-free phosphate buffered saline (PBS) and applied to a $10 \mathrm{ml}$
gelatin-Sepharose (Amersham/GE Health Care) column. The column was washed with $0.5 \mathrm{M}$ urea in PBS, and fibronectin was eluted with $4 \mathrm{M}$ urea in PBS. The purified protein was dialyzed against PBS and sterilized by filtration through a $0.2 \mu \mathrm{m}$ pore filter. Full length mouse recombinant tenascin-W was cloned, expressed and purified as described in Scherberich et al. (13). The rat anti-mouse tenascin-C monoclonal antibody (MTn-12) was characterized by Aufderheide and Ekblom (21), the rabbit polyclonal anti-mouse tenascin- $W$ was characterized by Scherberich et al. (13), and the anti-tenascin- $X$ rabbit polyclonal antibody was characterized by Matsumoto et al. (22). The mouse anti-vinculin monoclonal antibody was purchased from Sigma.

Substrata and cell culture. Tissue culture plastic dishes were coated with mouse fibronectin $(5 \mu \mathrm{g} / \mathrm{ml})$ or recombinant mouse tenascin-W $(5 \mu \mathrm{g} / \mathrm{ml}$ or 10 $\mu \mathrm{g} / \mathrm{ml})$ diluted in serum-free Dulbecco's Modified Eagle's Medium (DMEM) for $90 \mathrm{~min}$, rinsed in DMEM, blocked for $15 \mathrm{~min}$ with $1 \mathrm{mg} / \mathrm{ml}$ heat-inactivated bovine serum albumin (BSA), and rinsed $3 X$ in DMEM. Control dishes were incubated in DMEM without proteins and then rinsed and blocked as described. C2C12 cells (23) (a gift from Dr. Zach Hall, National Institute of Neurological Disorders and Stroke, National Institutes of Health, Bethesda, MD) or mouse embryo fibroblasts (see below) were washed in DMEM with $10 \%$ fetal calf serum (FCS), rinsed in DMEM without serum, and a $250 \mu$ aliquot was added to the coated substratum and the cells were incubated at $37^{\circ} \mathrm{C}$. After 90 min tenascin- $W$ diluted in warm DMEM was added to the medium of some of the cells being cultured on fibronectin-coated dishes (to a final concentration of 5 or $10 \mu \mathrm{g} / \mathrm{ml}$ ); a similar amount of warm DMEM alone was added to the other cultures at this time as a control. After at total of $2 \mathrm{hr}$ in culture the cells were fixed in $1 \%$ paraformaldehyde in DMEM for $30 \mathrm{~min}$, then rinsed 3X in PBS and processed for immunocytochemistry. All experiments were conducted in triplicate.

Immunocytochemistry, photography and image analysis. After fixation and rinsing the cells were blocked overnight in PBS with $0.5 \%$ BSA at $4{ }^{\circ} \mathrm{C}$, permeabilized with $0.1 \%$ Triton $\mathrm{X}-100$ for $5 \mathrm{~min}$, and incubated in anti-vinculin (see above) and/or TRITC-labeled phalloidin (Sigma) for $1 \mathrm{hr}$. The cells were then rinsed and incubated in secondary antibody (Alexa 488-labeled goat anti-mouse; Invitrogen) for $45 \mathrm{~min}$. Finally, the cells were rinsed in PBS containing DAPI (Sigma), rinsed and coverslipped. To measure cell areas, images of cells labeled with phalloidin were converted to high contrast, grayscale images and inverted. The number of black pixels was 
analyzed using Adobe Photoshop CS3 and converted to cell area by similarly analyzing a black square of a known size. Statistical differences $(p<0.05)$ were determined using a two-tailed t-test.

Fibroblast cultures and immunoblotting. Primary embryonic skin fibroblasts were isolated from 129/Sv mouse wildtype and TN-C knockout (20) embryos at embryonic day 15.5. The dissected skin was rinsed in $\mathrm{Ca}^{++} / \mathrm{Mg}^{++}$-free PBS, minced and digested in $5 \mathrm{ml} \quad 0.05 \%$ trypsin-EDTA (Gib$\mathrm{co} /$ Invitrogen) for $45 \mathrm{~min}$ at $37^{\circ} \mathrm{C}$. The digestion was stopped by adding the same volume of DMEM containing $10 \%$ FCS. Large debris was removed by centrifugation and cells were collected. Primary fibroblasts were plated in $10 \mathrm{~cm}$ dishes (Falcon) in $10 \mathrm{ml}$ DMEM $/ 10 \%$ FCS and grown to confluency. Cells were passaged once a week and spontaneously immortalized as described in Brellier et al. (24). To study tenascin expression, conditioned medium was collected, separated by SDS-PAGE, transferred and immunostained as described previously (12). Equal loading and transfer was confirmed with amido black. The intensities of the immunostained bands were measured with ImageQuant TL (v2005). Each tenascin value then was normalized to the intensity of an anti-vinculin immunostained band.

Wound healing and immunohistochemistry. Handling of the animals before and during the experiments, as well as the experiments themselves, were approved and supervised by the Swiss Agency for the Environment, Forests and Landscape and the Veterinary Service of the Canton of Bern. In addition we followed the guidelines of INSERM and the Federation of Laboratory Animal Science Associations. To study wound healing in mice we adapted an incisional tail wound model based on a previous study (25). For immunoblot analysis the tail tips of 3 SL-129 mice were cut generating $5 \mathrm{~mm}$ long fragments that were used as controls. These were compared with 5 mm long tail fragments from tenascin- $\mathrm{C}^{+/+}$or tenascin-C-1-SL-129 mice that contained wounds that were allowed to heal for 1 day, 3 days or 10 days. All fragments were cut into small pieces with a scalpel and homogenized with a mortar and pestle in $400 \mu \mathrm{l}$ of RIPA buffer. After 2 min of mixing, the solutions were centrifuged to remove debris. Samples were boiled in Laemmli sample buffer and stored at $-20^{\circ} \mathrm{C}$. For immunohistochemical analysis, wounded tail fragments like those described above were collected from tenascin- $\mathrm{C}^{+/+}$mice (2 male, 1 female, aged 3-7 weeks) and from tenascin- $\mathrm{C}^{-} /$- mice (2 male, 1 female, aged 5 weeks) and fixed overnight in $4 \%$ paraformaldehyde in PBS. The tissues were then rinsed, incubated overnight at $4{ }^{\circ} \mathrm{C}$ in $20 \%$ sucrose in PBS, and embedded in O.C.T. (Sakura). Frozen sections were collected on presubbed slides (Fisher). Dried slides were then rinsed, blocked in PBS with $0.5 \%$ BSA, and incubated overnight in MTn-12 (anti-tenascin-C), anti-tenascin- $X$ and anti-mouse tenascin- $W$ (see above). The next day the slides were rinsed, blocked and then incubated for $2 \mathrm{hr}$ in a mixture of diluted Alexa 488 labeled-goat anti-rat secondary antibody and Alexa 594 labeled-goat anti-rabbit secondary antibody (Invitrogen). Slides were rinsed in PBS with DAPI, then rinsed, coverslipped and photographed.

\section{Results and discussion}

The mouse myoblast cell line $\mathrm{C} 2 \mathrm{C} 12$ has the potential to transdifferentiate into osteoblasts, a cell type that we have previously shown can bind to tenascin-W $(13,17)$. We selected C2C12 cells for this study because we found that these cells adhere to tenascin-W, yet they do not express tenascin- $W$ in the absence of BMP2 (13) and they were used in an earlier study illustrating the anti-adhesive properties of tenascin-C (5). C2C12 cells cultured for $2 \mathrm{hr}$ in the absence of serum on tissue culture plastic blocked with BSA will attach and spread, resulting in morphologically diverse multipolar cells with many small lamellae and short phalloidin-labeled stress fibers (Fig. 1A). In contrast, when these cells are cultured for $2 \mathrm{hr}$ on tissue culture plastic coated with $5 \mu \mathrm{g} / \mathrm{ml}(\sim 25$ $\mathrm{nM})$ of mouse fibronectin blocked with BSA they spread and form large lamellae as well as stress fibers ending in anti-vinculin labeled focal adhesion complexes (Fig. 1B). When cultured on $10 \mu \mathrm{g} / \mathrm{ml}(\sim 50 \mathrm{nM})$ mouse tenascin-W blocked with BSA the $\mathrm{C} 2 \mathrm{C} 12$ cells fail to spread and form lamellae. Instead, cells on tenascin-W are typically triangular or polygonal and have numerous small, actin-rich processes (Fig. 1C). Stress fibers are not seen, and the anti-vinculin stains the cytoplasm of these cells instead of the focal adhesion complexes seen when cells are cultured on fibronectin. On mixed fibronectin/tenascin-W substrata an intermediate morphology is usually observed: the $\mathrm{C} 2 \mathrm{C} 12$ cells do not form large lamellae, but a few anti-vinculin-positive focal adhesion complexes are typically present (Fig. 1D). There were statistically fewer $(p<0.001)$ anti-vinculin-positive focal adhesions in $\mathrm{C} 2 \mathrm{C} 12$ cells cultured on mixed substrata $(8.5 \pm$ $9.2, \mathrm{n}=11)$ than on fibronectin alone $(26.7 \pm 14.5, \mathrm{n}=$ 10). The adhesion modulating effects of substratum-bound tenascin-W were also observed with soluble tenascin-W. When $\mathrm{C} 2 \mathrm{C} 12$ cells were first allowed to attach and spread on fibronectin-coated substrata for $90 \mathrm{~min}$ and tenascin- $W$ was then added to the medium for an additional $30 \mathrm{~min}$ prior to fixation and staining, the cells typically acquired the polygonal 
morphology and short actin-rich processes that were also observed with cells cultured on tenascin-W alone (Fig. 1E).

The different morphologies of $\mathrm{C} 2 \mathrm{C} 12$ cells following culture on fibronectin, tenascin-W, mixtures of fibronectin and tenascin- $W$, and on fibronectin with soluble tenascin- $W$, are identical to the morphologies we previously described for $\mathrm{C} 2 \mathrm{C} 12$ cells cultured under similar conditions on tenascin- $\mathrm{C}$ and fibronectin (5). In our previous study we observed stress fibers developing in $\mathrm{C} 2 \mathrm{C} 12$ cells 90 min after culture on tissue culture plastic coated with $50 \mathrm{nM}$ fibronectin (about twice the concentration we used here), while cells cultured on tissue culture plastic coated with 50
$\mathrm{nM}$ tenascin-C are polygonal with short, actin-rich processes indistinguishable from cells cultured on tenascin-W. One potentially important difference between our previous study and the current one has to do with the species of origin of the fibronectin and tenascin: Fischer et al. (5) used fibronectin purified from horse serum and recombinant chicken tenascin- $C$, but here we used mouse fibronectin and recombinant mouse tenascin-W. This seemed appropriate, as there may be a functional integrin-binding RGD motif found in the second fibronectin type III domain of mouse tenascin-W (13) that is missing in avian (and human) tenascin-W (26).
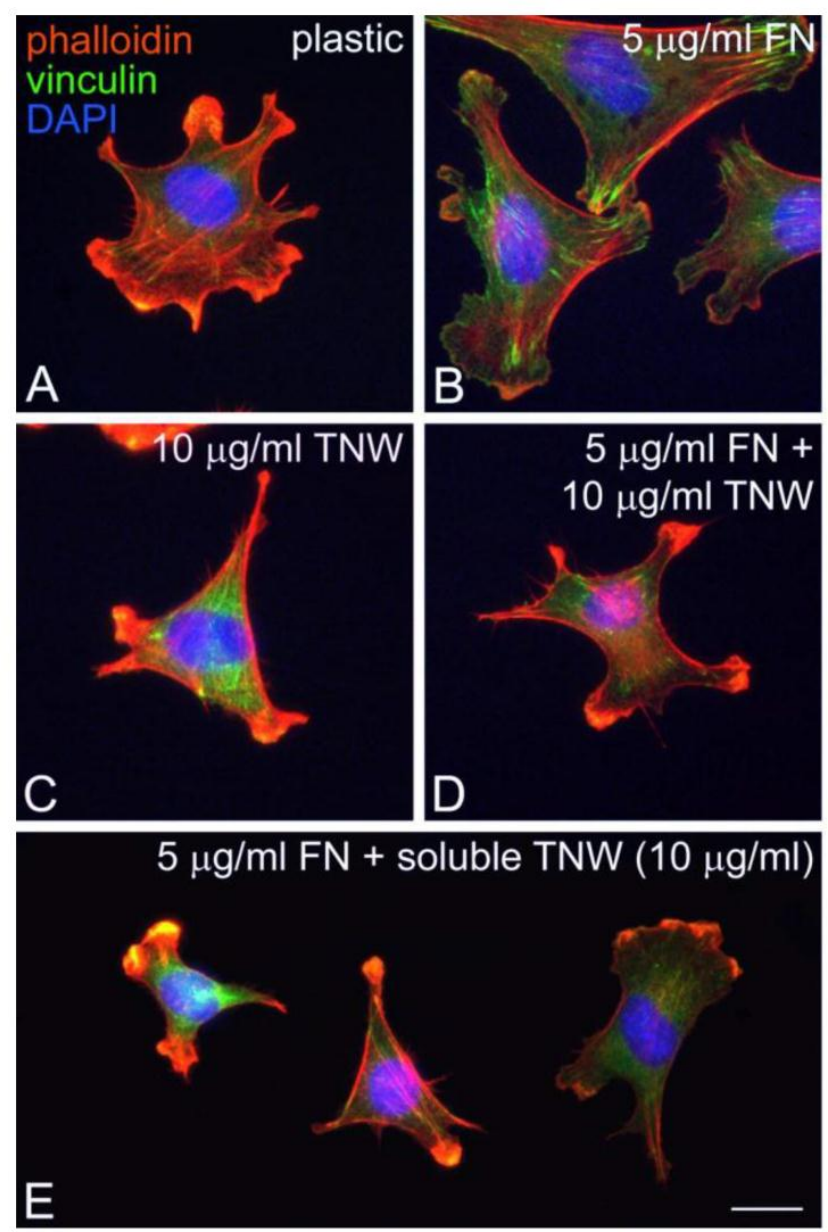
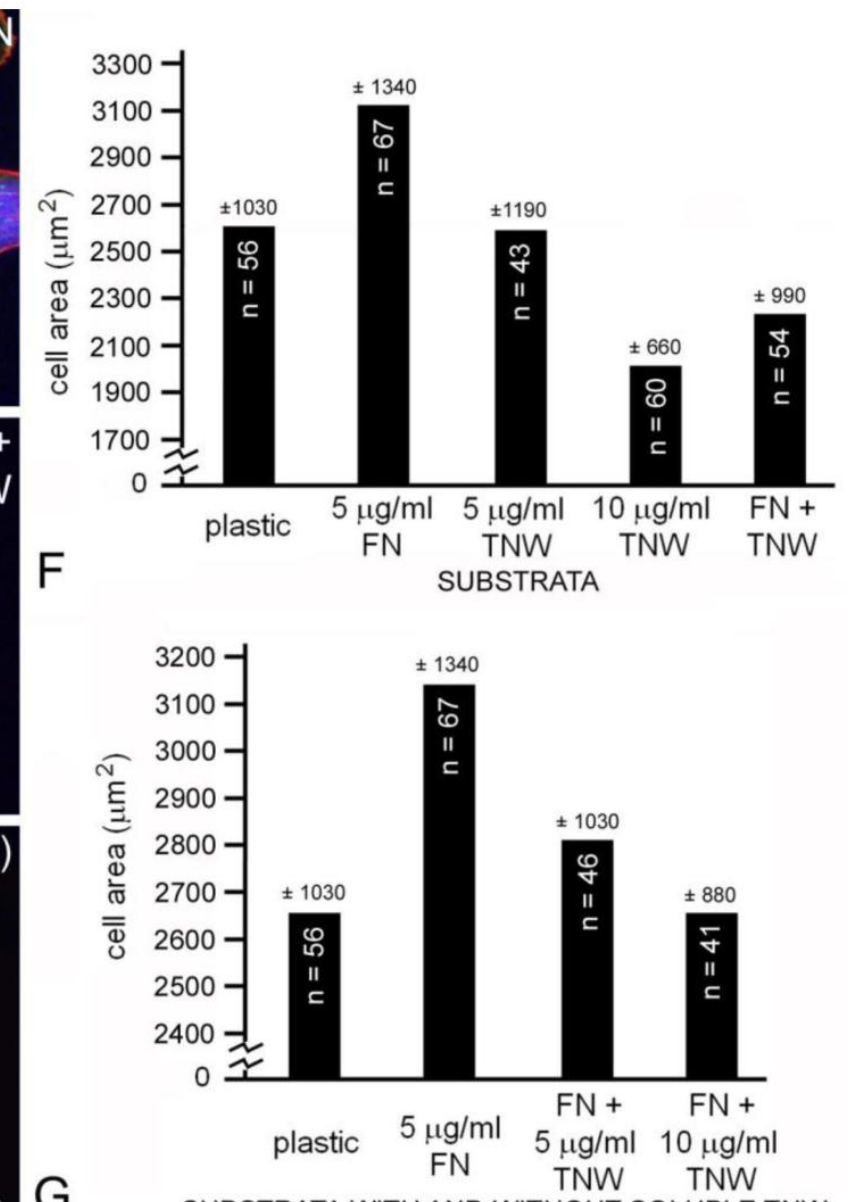

SUBSTRATA WITH AND WITHOUT SOLUBLE TNW

Fig. I. $\mathrm{C} 2 \mathrm{C} / 2$ cells cultured on tissue culture plastic (A), fibronectin (B), tenascin-W (C), a mixture of fibronectin and tenascin-W (D) or on fibronectin with tenascin-W added to the medium (E). After $2 \mathrm{hr}$ the cells were fixed and stained with TRITC-labeled phalloidin (red) to show polymerized actin, anti-vinculin (green) to show focal adhesion complexes, and the nuclear marker DAPI (blue). C2CI2 cells spread and form stress fibers and numerous focal adhesion complexes on fibronectin, but are polygonal on tenascin-W and have numerous short, actin-rich processes. Cells cultured on mixtures of fibronectin and tenascin-W, or on fibronectin with tenascin-W in the medium, resemble cells cultured on tenascin-W alone. Total areas of cells cultured under the conditions indicated were measured and compared (sample size and standard deviations are indicated; F, G). C2Cl2 cells are significantly more spread on $5 \mu \mathrm{g} / \mathrm{ml}$ fibronectin than on tissue culture plastic, and are significantly less spread on $10 \mu \mathrm{g} / \mathrm{ml}$ tenascin-W than on tissue culture plastic alone. The $\mathrm{C} 2 \mathrm{Cl} 2 \mathrm{cells}$ are also significantly less spread on the mixture of tenascin-W and fibronectin than on fibronectin alone, and on fibronectin with $10 \mu g / \mathrm{ml}$ tenascin-W in the medium than on fibronectin alone. Scale bar $=25 \mu \mathrm{m}$. 


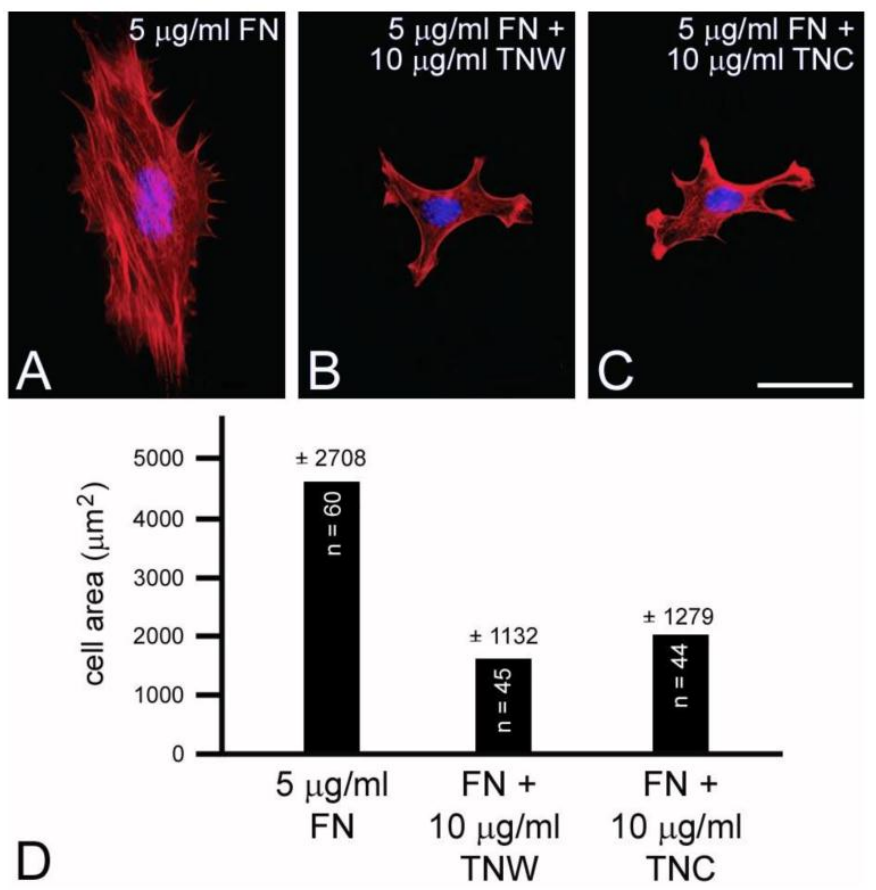

Fig. 2. Mouse embryo fibroblasts cultured on fibronectin (A) or combinations of fibronectin and tenascin-W (B) or fibronectin and tenascin-C (C) stained with TRITC-labeled phalloidin (red) and DAPI (blue). Mouse embryo fibroblasts cultured for 2 hr on fibronectin spread and form stress fibers; mouse embryo fibroblasts cultured on fibronectin mixed with tenascin-W or tenascin- $C$ are stellate and fail to form lamellipodia or stress fibers. When the total cell area is measured, there is a significant decrease in the area of cells cultured on the mixed substrata when compared with fibronectin alone (D). Sample size and standard deviations are indicated. Scale bar $=100 \mu \mathrm{m}$.

C2C12 cells cultured on mixed fibronectin and tenascin-W substrata have fewer anti-vinculin-positive focal adhesion complexes than cells cultured on fibronectin alone, and after the addition of tenascin- $W$ to the medium $\mathrm{C} 2 \mathrm{C} 12$ cells cultured on fibronectin fail to elaborate lamellae and stress fibers. To quantify the effects of tenascin-W on cell morphology and to determine the effects of different concentrations of tenascin- $W$, the total area of $\mathrm{C} 2 \mathrm{C} 12$ cells under different culture conditions was measured and compared (Fig. 1F, G). As expected, cells cultured on tissue culture plastic coated with 5 $\mu \mathrm{g} / \mathrm{ml}$ fibronectin are more spread than cells cultured on tissue culture plastic alone. No effect on cell area was observed when $\mathrm{C} 2 \mathrm{C} 12$ cells were cultured on dishes coated with $5 \mu \mathrm{g} / \mathrm{ml}$ tenascin-W, but on 10 $\mu \mathrm{g} / \mathrm{ml}$ of tenascin-W the cell area is significantly less than the area of cells cultured on fibronectin or on tissue culture plastic alone. Cells cultured on mixed fibronectin/tenascin-W substrata are less spread than cells cultured on fibronectin alone, as are cells cultured on fibronectin with $10 \mu \mathrm{g} / \mathrm{ml}$ tenascin-W in the medium. These results show that tenascin- $W$ has the same effects on $\mathrm{C} 2 \mathrm{C} 12$ cell morphology as tenascin-C, and that tenascin- $W$ shares the adhesion modulating activity of tenascin- $\mathrm{C}$ when cells are cultured on fibronectin. The effects of tenascin-W on cell spreading are not limited to $\mathrm{C} 2 \mathrm{C} 12$ cells. When mouse embryo fibroblasts are cultured on $5 \mu \mathrm{g} / \mathrm{ml}$ fibronectin they spread and form an extensive array of stress fibers (Fig. 2A). In contrast, mouse embryo fibroblasts cultured on a combination of fibronectin and tenascin- $W$ fail to spread and form stress fibers, and instead acquire the multipolar morphology described above for C2C12 cells cultured on tenascin-W (Fig. 2B). A similar morphology is seen when mouse embryo fibroblasts are cultured on combinations of $5 \mu \mathrm{g} / \mathrm{ml} \mathrm{fi-}$ bronectin and $10 \mu \mathrm{g} / \mathrm{ml}$ of tenascin-C (Fig. 2C). When the areas of mouse embryo fibroblasts cultured under these conditions are measured and compared, they are significantly $(p<0.001)$ less on the mixed substrata containing tenascin- $W$ and tenascin- $C$ than on fibronectin alone (Fig. 2D).

Tenascin- $C$ is typically expressed by cultured dermal fibroblasts (27) and is upregulated in granulation tissue at the margins of healing skin wounds (19). To determine if tenascin- $W$ may be able to compensate for the tenascin- $\mathrm{C}$ missing from the granulation tissue of tenascin-C knockout mice, primary fibroblasts from the dermis of either tenascin- $\mathrm{C}^{+/+}$or 
tenascin-C -/- mice were examined for tenascin-W expression by immunoblotting. Tenascin- $W$ expression was observed in the cells from the dermis of tenascin-C $/-$ mice, but not in the control cells (Fig. $3 A)$. The acquisition of tenascin- $W$ expression came over time, with repeated passages (Fig. 3B). This suggests that at least some cells that normally express tenascin- $C$ are able to upregulate tenascin- $W$ following knockout of tenascin-C. To determine if a similar upregulation takes place in vivo during the healing of skin wounds, fragments of epidermis and dermis from unwounded tails and epidermis, dermis and early granulation tissue from wounds that had healed for 1-10 days were homogenized and studied for the expression of tenascin- $C$ and tenascin-W by immunoblot analysis (Fig. 3C). Tenascin-C is upregulated 2.7 fold 3 days after wounding and 4.5 fold 10 days after wounding. There is no difference between tenascin-W expression in wounds of tenascin- $C^{+/+}$ versus tenascin-C -/- mice with a slight upreguation of tenascin-W after 2 days (average 1.5 fold) and no upregulation 10 days after wounding. This was confirmed by examining frozen sections through wounds in the tails of tenascin- $\mathrm{C}^{+/+}$and tenascin- $\mathrm{C}^{-/-}$mice 3 days following injury with anti-tenascin- $C$ and anti-tenascin-W. As reported previously (19), tenascin-C is abundant in the early granulation tissue of the healing wounds (Fig. 4A). In contrast, tenascin-W is found in patches in the normal skin near the dermal/epidermal junction in regions corresponding to the connective tissue septae that run from the epidermis to deep connective tissue (the 'wrinkles' in the tail), but it is not present in the early granulation tissue (Fig. 4A). In the healing cutaneous wounds in the tail of the tenascin- $C$ knockout mice, no tenascin- $C$ immunoreactivity was seen, and the distribution of tenascin- $W$ was identical to that seen in the control dermis (Fig. 4B). Therefore, even though tenascin-W shares the adhesion modulating properties of tenascin- $\mathrm{C}$ in vitro, and it can be upregulated in fibroblasts derived from the dermis of tenascin-C-/- mice, it is not upregulated during wound healing in the skin of the tenascin-C knockout mice and is unlikely to be compensating for the missing tenascin- $C$ in this system. The observation made by others (20) that levels of fibronectin appear to be lower in the wounds of tenascin-C-/- mice may offer an explanation for the apparently normal phenotype. Moreover, tenascin- $X$ has well documented anti-adhesive properties (12) and may play a role in compensating for the missing tenascin-C. However, antibodies to tenascin- $X$ reveal the previously described pattern of expression in the epidermis and deep dermis (22) in sections of healing wounds from control mice (Fig. 4C), but do not show upregulation in the early granulation tissue of wounds in the tenascin-C -/- mice (Fig. 4D).
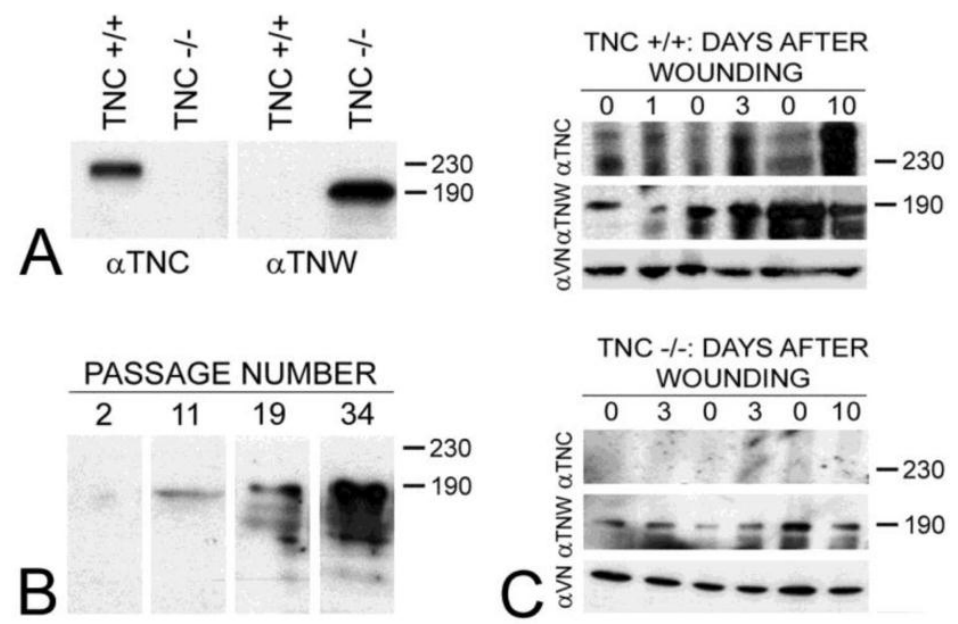

Fig. 3. The expression of tenascin-C ( $\alpha$ TNC) and tenascin-W ( $\alpha$ TNW) by primary fibroblasts from tenascin- $\mathrm{C}^{+/+}$and tenascin- $\mathrm{C}^{-/-}$dermis were compared by immunoblotting (A). Fibroblasts from normal dermis express tenascin-C, but fibroblasts derived from tenascin-C knockout skin expresses tenascin-W. Amido black was used to demonstrate equal loading (not shown). The expression of tenascin-W by the fibroblasts derived from tenascin-C-l- dermis increased with passaging (B). The expression of tenascins- $\mathrm{C}$ and $-\mathrm{W}$ was also examined by immunoblotting homogenates of control and wounded skin (C). There is an increase in the expression of tenascin-C 3 (2.7 fold) and I0 days (4.5 fold) following wounding. Tenascin-W expression is upregulated I.5 fold 3 days following wounding, but is not upregulated after 10 days both in tenascin- $\mathrm{C}+/+$ and tenascin- $\mathrm{C}-/-$ mice. Anti-vinculin $(\mathrm{VN})$ was used to normalize the changes in the intensity of the anti-tenascins. In wounds from the tenascin-C-/- mice, the expression of tenascin-W remains unchanged. Apparent molecular weights are indicated by size standards $(\mathrm{kDa})$. 

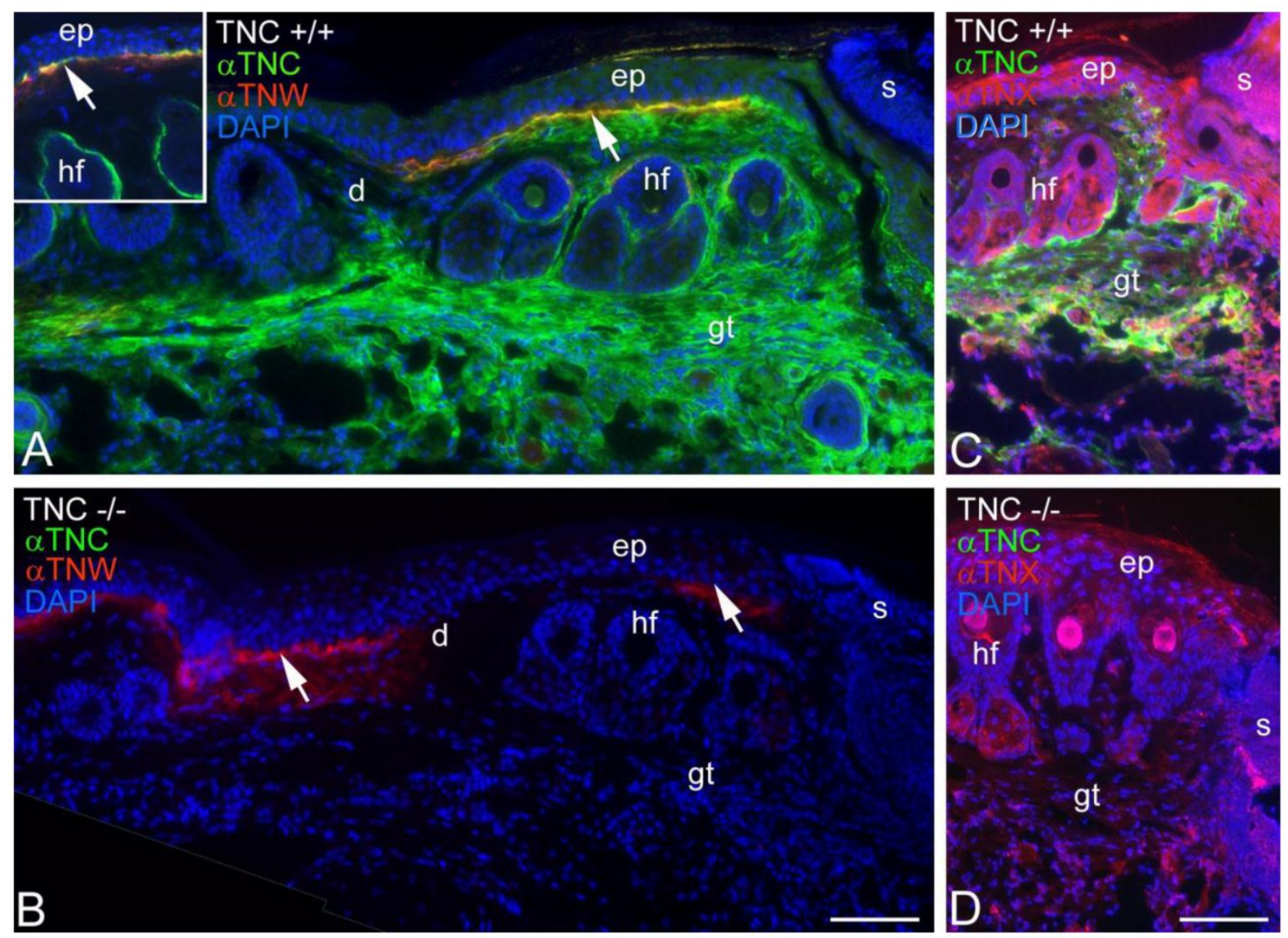

Fig. 4. Tenascin- $C$ and tenascin- $W$ expression in healing wounds was confirmed by immunohistochemistry (A, B). Three days following an incision in the skin of a tenascin- $\mathrm{C}^{+/+}$mouse tail, anti-tenascin-C (green) stains the early granulation tissue (gt) adjacent to the wound (A). Anti-tenascin-W (red) stains patches at the border of the epidermis (ep) and dermis (d; arrow); patchy staining was seen both near and far from the scab (s) and appears to coincide with the fibrous septum than runs from the epidermis to deeper connective tissue. In an unwounded tail, tenascin- $\mathrm{C}$ immunoreactivity is limited to the dermal-epidermal junction and the capsule around hair follicles (hf; inset). In a similar wound in the skin of a tenascin-C-- mouse the anti-tenascin-W staining is unchanged (B). The expression of tenascin-X (red) in the tail wounds was also studied by immunohistochemistry (C, D). Tenascin-X is found in the epidermis (e), deep dermis and in structures associated with the hair follicles (hf), but it is not upregulated in the early granulation tissue (gt) of wild type or tenascin-C knockout mouse wounds. Scale bar $=100 \mu \mathrm{m}$.

Our results show that tenascin-W shares the adhesion modulating properties of other members of the tenascin gene family. The molecular mechanisms underlying these properties remain unknown. Future studies should be directed to determining if tenascin-W can bind to fibronectin, and if it does, if it binds to the same region as tenascin-C. In addition, putative integrin binding domains have been identified in tenascin- $W$, and the integrins that recognize these sites and the signaling pathways mediated by these integrins need to be identified. Initial studies point to a conserved KGD motif playing a role in regulating the anti-adhesive properties of tenascin-W (17) and $\alpha 8$ integrins promoting tenascin- $W$ mediated motility, at least in tenascin-W from mouse (14).

\section{Acknowledgements}

We thank Jean-Francois Spetz for help with the skin wound models. This work was supported by the Novartis Research Foundation and Swiss National Science Foundation grants to R.C.E. and M.C. (31003A-120235/31003A-135584) and to J.C.S. (3100A0-109874/310030-125397), and by grants to G.O. from the Institut National du Cancer, Institut National de la Santé et de la Recherche Médicale, Association pour la Recherche contre le Cancer, Agence National de la recherche and the Hospital Hautepierre. 


\section{Conflict of Interests}

The authors have declared that no conflict of interest exists.

\section{References}

1. Chiquet-Ehrismann R, Tucker RP. Tenascins and the importance of adhesion modulation. In: Hynes RO and Yamada KM, eds. Extracellular Matrix Biology. Cold Spring Harb Perspect Biol; 2012. doi: 10.1101/cshperspect.a004960

2. Chiquet-Ehrismann R, Mackie EJ, Pearson CA, Sakakura T. Tenascin: an extracellular matrix protein involved in tissue interactions during fetal development and oncogenesis. Cell 1986; 47(1): 131-139.

3. Chiquet-Ehrismann R, Kalla P, Pearson CA, Beck K, Chiquet M. Tenascin interferes with fibronectin action. Cell 1988; 53(3): 383-390.

4. Murphy-Ullrich JE, Lightner VA, Aukhil I, Yan YZ, Erickson $\mathrm{HP}$, Hook M. Focal adhesion integrity is downregulated by the alternatively spliced domain of human tenascin. J Cell Biol 1991; 115(4): 1127-1136.

5. Fischer D, Tucker RP, Chiquet-Ehrismann R, Adams JC. Cell-adhesive responses to tenascin-C splice variants involve formation of fascin microspikes. Mol Biol Cell 1997; 8(10): 2055-2075.

6. Huang W, Chiquet-Ehrismann R, Moyano JV, Garcia-Pardo A, Orend $\mathrm{G}$. Interference of tenascin- $\mathrm{C}$ with syndecan- 4 binding to fibronectin blocks cell adhesion and stimulates tumor cell proliferation. Cancer Res 2001; 61(23): 8586-8594.

7. Midwood KS, Valenick LV, Hsia HC, Schwarzbauer JE. Coregulation of fibronectin signaling and matrix contraction by tenascin-C and syndecan-4. Mol Biol Cell 2004; 15(12): 5670-5677.

8. Pesheva P, Probstmeier R, Skubitz AP, McCarthy JB, Furcht LT, Schachner M. Tenascin-R (J1 160/180 inhibits fibronectin-mediated cell adhesion--functional relatedness to tenascin-C. J Cell Sci 1994; 107 (Pt 8): 2323-2333.

9. Angelov DN, Walther M, Streppel M, Guntinas-Lichius O, Neiss WF, Probstmeier R, Pesheva P. Tenascin-R is antiadhesive for activated microglia that induce downregulation of the protein after peripheral nerve injury: a new role in neuronal protection. J Neurosci 1998; 18(16): 6218-6229.

10. Tucker RP, Hagios C, Santiago A, Chiquet-Ehrismann R. Tenascin- $Y$ is concentrated in adult nerve roots and has barrier properties in vitro. J Neurosci Res 2001; 66(3): 439-447.

11. Elefteriou F, Exposito JY, Garrone R, Lethias C. Cell adhesion to tenascin- $X$ mapping of cell adhesion sites and identification of integrin receptors. Eur J Biochem 1999; 263(3): 840-848.

12. Fujie S, Maita H, Ariga H, Matsumoto K. Tenascin-X induces cell detachment through p38 mitogen-activated protein kinase activation. Biol Pharm Bull 2009; 32(10): 1795-1799.

13. Scherberich A, Tucker RP, Samandari E, Brown-Luedi M, Martin D, Chiquet-Ehrismann R. Murine tenascin-W: a novel mammalian tenascin expressed in kidney and at sites of bone and smooth muscle development. J Cell Sci 2004; 117(Pt 4): 571-581.

14. Scherberich A, Tucker RP, Degen M, Brown-Luedi M, Andres AC, Chiquet-Ehrismann R. Tenascin- $W$ is found in malignant mammary tumors, promotes alpha8 integrin-dependent motility and requires p38MAPK activity for BMP-2 and TNF-alpha induced expression in vitro. Oncogene 2005; 24(9): 1525-1532.

15. Meloty-Kapella CV, Degen M, Chiquet-Ehrismann R, Tucker RP. Avian tenascin-W: expression in smooth muscle and bone, and effects on calvarial cell spreading and adhesion in vitro. Dev Dyn 2006; 235(6): 1532-1542.
16. Degen M, Brellier F, Kain R, Ruiz C, Terracciano L, Orend G, Chiquet-Ehrismann R. Tenascin-W is a novel marker for activated tumor stroma in low-grade human breast cancer and influences cell behavior. Cancer Res 2007; 67(19): 9169-9179.

17. Meloty-Kapella CV, Degen M, Chiquet-Ehrismann R, Tucker RP. Effects of tenascin-W on osteoblasts in vitro. Cell Tissue Res 2008; 334(3): 445-455.

18. Saga Y, Yagi T, Ikawa Y, Sakakura T, Aizawa S. Mice develop normally without tenascin. Genes Dev 1992; 6(10): 1821-1831.

19. Mackie EJ, Halfter W, Liverani D. Induction of tenascin in healing wounds. J Cell Biol 1988; 107(6 Pt 2): 2757-2767.

20. Forsberg E, Hirsch E, Frohlich L, Meyer M, Ekblom P, Aszodi A, Werner S, Fassler R. Skin wounds and severed nerves heal normally in mice lacking tenascin-C. Proc Natl Acad Sci U S A 1996; 93(13): 6594-6599.

21. Aufderheide E, Ekblom P. Tenascin during gut development: appearance in the mesenchyme, shift in molecular forms, and dependence on epithelial-mesenchymal interactions. J Cell Biol 1988;107(6 Pt 1): 2341-2349.

22. Matsumoto K, Saga Y, Ikemura T, Sakakura T, Chiquet-Ehrismann R. The distribution of tenascin-X is distinct and often reciprocal to that of tenascin-C. J Cell Biol 1994; 125(2):483-493.

23. Gordon $\mathrm{H}, \mathrm{Hall} \mathrm{ZW}$. Glycosaminoglycan variants in the $\mathrm{C} 2$ muscle cell line. Dev Biol 1989; 135(1): 1-11.

24. Brellier F, Hostettler K, Hotz HR, Ozcakir C, Çöloğlu SA, Togbe D, Ryffel B, Roth M, Chiquet-Ehrismann R. Tenascin-C triggers fibrin accumulation by downregulation of tissue plasminogen activator. FEBS Lett 2011; 585(6): 913-920.

25. Kretz M, Euwens C, Hombach S, Eckardt D, Teubner B, Traub $\mathrm{O}$, Willecke $\mathrm{K}, \mathrm{Ott} \mathrm{T}$. Altered connexin expression and wound healing in the epidermis of connexin-deficient mice. J Cell Sci 2003; 116(Pt 16): 3443-3452.

26. Tucker RP, Drabikowski K, Hess JF, Ferralli J, Chiquet-Ehrismann R, Adams JC. Phylogenetic analysis of the tenascin gene family: evidence of origin early in the chordate lineage. BMC Evol Biol 2006; 6: 60.

27. Pearson CA, Pearson D, Shibahara S, Hofsteenge J, Chiquet-Ehrismann R. Tenascin: cDNA cloning and induction by TGF-beta. EMBO J 1988; 7(10): 2977-2982. 